University of Nebraska - Lincoln

DigitalCommons@University of Nebraska - Lincoln

\title{
Canopy Architecture and Morphology of Switchgrass Populations Differing in Forage Yield
}

\author{
Daren D. Redfearn \\ LSU Agriculture Center, dredfearn2@unl.edu \\ Kenneth J. Moore \\ lowa State University \\ Kenneth P. Vogel \\ University of Nebraska-Lincoln, kvogel1@unl.edu \\ Steven S. Waller \\ University of Nebraska-Lincoln, swaller1@unl.edu \\ Robert B. Mitchell \\ Texas Tech University, rob.mitchell@ars.usda.gov
}

Follow this and additional works at: https://digitalcommons.unl.edu/usdaarsfacpub

Redfearn, Daren D.; Moore, Kenneth J.; Vogel, Kenneth P.; Waller, Steven S.; and Mitchell, Robert B., "Canopy Architecture and Morphology of Switchgrass Populations Differing in Forage Yield" (1997). Publications from USDA-ARS / UNL Faculty. 1892.

https://digitalcommons.unl.edu/usdaarsfacpub/1892

This Article is brought to you for free and open access by the U.S. Department of Agriculture: Agricultural Research Service, Lincoln, Nebraska at DigitalCommons@University of Nebraska - Lincoln. It has been accepted for inclusion in Publications from USDA-ARS / UNL Faculty by an authorized administrator of DigitalCommons@University of Nebraska - Lincoln. 


\title{
Canopy Architecture and Morphology of Switchgrass Populations Differing in Forage Yield
}

\author{
Daren D. Redfearn,* Kenneth J. Moore, Kenneth P. Vogel, Steven S. Waller, and Robert B. Mitchell
}

\begin{abstract}
Phenotypic selection has been used to improve forage yield and in vitro dry matter disappearance (IVDMD), but the effects on canopy architecture and morphology are not understood. Our objectives were to determine if canopy architecture and morphology can explain genotype $\times$ environment $(G \times E)$ yield differences in switchgrass (Panicum virgatum $\mathbf{L}$.) and to evaluate canopy architecture and morphology as selection criteria for increasing yield. This study was conducted in 1993 near Mead, NE, and near Ames, IA. The experimental design was a randomized complete block experiment with a split-plot arrangement of four replicates at each location. Whole plots were tiller population and subplots were sward maturity. Tiller populations were harvested on 9 June, 19 July, and 27 August at Ames and on 10 June, 27 July, and 26 August at Mead and were classified morphologically. Tillers were separated into primary yield components and dried at $55^{\circ} \mathrm{C}$ to determine total forage yield and dry matter contribution of morphological components. Genotype $x$ environment interactions occurred for total forage yield and tiller density. Previous phenotypic selection for increased forage yield and IVDMD apparently altered morphological changes within the canopy of selected switchgrass populations. The most apparent changes were development of additional collared leaves and internodes in some populations across locations. Although canopy architecture may not be a useful selection criterion because of variability associated with individual canopy traits, indirect measurements showed that leaf area index (LAI) has some potential as a selection criterion for increasing total forage yield. However, selection for individual canopy traits may be most effective for modifying sward growth habits.
\end{abstract}

D.D. Redfearn, LSU Agric. Ctr., S.E. Res. Stn., P.O. Drawer 567, Franklinton, LA 70438; K.J. Moore, Dep. of Agronomy, Iowa State Univ., Ames, IA 50011; K.P. Vogel, USDA-ARS and Dep. of Agronomy, and S.S. Waller, Dep. of Agronomy, Univ. of Nebraska, Lincoln, NE 68583; and R.B. Mitchell, Dep. of Range, Wildlife, and Fisheries Management, Texas Tech Univ., Lubbock, TX 79409. The research reported in this article is a portion from the dissertation submitted by the senior author in partial fulfilment of the requirements for the Ph.D. degree from the Univ. of Nebraska. Research funded in part by the U.S. Dep. of Energy Biomass Fuels Program, Oak Ridge Natl. Lab. Contract no. DE-A105900R2 1954. Joint contribution from the Nebraska Agric. Exp. Stn. and lowa Agric. and Home Econ. Exp. Stn. Published as Journal Series no. 11442, Nebraska Agric. Exp. Stn. Received 6 Mar 1996. *Corresponding author (dredfearn@agctr.lsu.edu).

Published in Agron. J. 89:262-269 (1997).
Nwit WITCHGRASS is a native, perennial warm-season grass with a wide range of adaptation throughout North America (Stubbendieck et al., 1992). If properly managed, switchgrass can provide a reliable source of forage during the summer, when cool-season grasses are low in productivity. In Pennsylvania, nonfertilized 'Blackwell' switchgrass harvested at early head emergence produced 4.7 $\mathrm{Mg} \mathrm{ha}^{-1}$ (Griffin and Jung, 1981). Similarly, Henry et al. (1976) reported yields of more than $6.0 \mathrm{Mg} \mathrm{ha}^{-1}$ over a 3-yr period for nonfertilized Blackwell switchgrass grown in Kentucky. Persistence was not affected by stage of morphological development at first harvest, but regrowth potential decreased with later first-harvest date (Anderson and Matches, 1983). Harvest frequency had a large influence on stand persistence. Harvesting two or three times yearly decreased switchgrass stands by $58 \%$, but a single harvest during the active growing period decreased stands by only $39 \%$ (Newell and Keim, 1947).

Quantity of forage, either grazed or mechanically harvested, is determined by size, architecture, and developmental status of tiller populations within the sward. Traits of canopy architecture include plant and tiller densities, LAI, leaf mean tilt angle (MTA, or the angle of inclination of the leaf tip), leaf blade length and width, and internode length. Changes in plant morphology that occur during primary growth can be important determinants of potential productivity in perennial forage grasses. Because yield is controlled by many genes, heritability of yield in switchgrass is low (Godshalk et al., 1986; Newell and Eberhart, 1961; Talbert et al., 1983). Tan et al. (1977) concluded that leaf area per tiller and tiller density were two fundamental factors that affected yield of a seven-parent diallel cross in smooth bromegrass (Bromus inermis Leyss.). Yield of perennial ryegrass

Abbreviations: DM, dry matter; DW, dry weight; $\mathrm{G} \times \mathrm{E}$, genotype $\times$ environment; IVDMD, in vitro dry matter disappearance; LAI, leaf area index; MSC, mean stage by count; MSW, mean stage by weight; MTA, mean tilt angle; $L \times P$, location $\times$ population. 
(Lolium perenne L.) was positively correlated with leaf length and LAI (Rhodes, 1969, 1975), and perennial ryegrass varieties with erect foliage were more productive than varieties with less erect canopies (Rhodes, $1968,1971)$. Erect leaf angles may allow more light to illuminate a greater leaf area and thus possibly increase forage productivity. Maize (Zea mays L.) had greater yield from canopies with erect leaves than canopies without erect leaves (Pendleton et al., 1968). Light entering a canopy of erect leaves was spread over a larger photosynthetic area than in prostrate varieties, resulting in greater photosynthetic efficiency.

An improved understanding of the associated effects of individual morphological components and morphological developmental of tiller populations within a sward on yield may improve forage management and use. For example, increased yields have resulted from selection of plants with larger tillers and leaf blades in reed canarygrass (Phalaris arundinacea L.) and tall fescue (Festuca arundinacea Schreb.) (Carlson et al., 1983; Nelson and Sleper, 1983). High yielding forage species are favored by accumulation of a large number of reproductive tillers. For North American tallgrass prairie species, including switchgrass, the relationship of yield to tiller number per unit area has not been determined.

Investigation of canopy architecture within a grass sward may help explain how plants utilize their aerial environment. In forage crops, aboveground vegetation $X$ environment interactions are largely controlled by canopy architecture (Welles and Norman, 1991) as it relates to the distribution, areas and shapes of leaves, stems, and inflorescences. Leaf area index, leaf MTA, foliage density, and estimates of foliage arrangement often have been used to describe canopy structure. Brougham (1958) suggested that inter- and intraspecies variation in LAI would become evident as the growing season progressed.

There has been minimal detailed research on switchgrass to describe development of switchgrass canopy structure. Measurements of sward developmental morphology in relation to tiller and canopy architecture for improved switchgrass varieties are limited. Elementary information on the growth and development of the canopy structure is required to use switchgrass successfully as a forage crop.

Our objectives were to determine if traits of canopy architecture can explain observed $\mathrm{G} \times \mathrm{E}$ differences in switchgrass populations known to differ in yield and to evaluate canopy architecture as a potential selection criterion for increasing yield in a switchgrass breeding program.

\section{MATERIALS AND METHODS}

This study was conducted during 1993 at the University of Nebraska Agricultural Research and Development Center near Mead, NE, on a Sharpsburg silty clay loam (fine, montmorillonitic, mesic Typic Argiudoll) and at the Iowa State University Agronomy and Agricultural Engineering Research Center near Ames, IA, on a Webster silty clay loam (fine-loamy, mixed, mesic Typic Endoaquolls). The experimental plots used in the study were switchgrass (Panicum virgatum L.) yield trials established to evaluate genotype and $\mathrm{G} \times \mathrm{E}$ interactions in switchgrass (Hopkins et al., 1995). This study was structured as an in-depth investigation of the genotype and $G \times E$ study previously reported by Hopkins et al. (1995). More specifically, six subset populations were used to represent the extent of variation that existed for yield and also populations that showed significant $\mathrm{G} \times \mathrm{E}$ responses. The plots were established in the spring of 1990 as a randomized complete block design with four replicates of 20 switchgrass populations at each location. Plot size at Ames was 3.7 by $0.9 \mathrm{~m}$; plot size at Mead was 4.5 by $1.5 \mathrm{~m}$. Each plot was subdivided into three subplots, to be harvested randomly for the three different sward maturities.

This study used three commercially available switchgrass cultivars (Trailblazer, Pathfinder, and Cave-in-Rock) and three experimental populations selected either for high or low IVDMD or dry matter (DM) yield. These experimental populations had been developed by the USDA-ARS forage grass breeding project located at Lincoln, NE. Descriptions of genetic backgrounds of the switchgrass populations follow the nomenclature previously detailed by Vogel et al. (1991) and Hopkins et al. (1993). Trailblazer was developed by one cycle of selection for high IVDMD in the Ey $\times$ FF population that originated from selections made in Nebraska and Kansas; it is similar in maturity and adaptation to Pathfinder but with increased IVDMD (Vogel et al., 1991). Pathfinder is a synthetic cultivar developed from selections made in Nebraska and Kansas (Newell, 1968). Cave-in-Rock was developed from selections made in southern Illinois and developed by the Natural Resources Conservation Service Plant Material Center in Ellsberry, MO. The three experimental populations were Ey $\times$ FF Low IVDMD Cycle 1, Ey $\times$ FF High IVDMD Cycle 3, and Pathfinder High Yield-DMD Cycle 2. The Ey $\times$ FF Low IVDMD Cycle 1 population was selected from the same base population as Trailblazer and is identical to the population described by Vogel et al. (1991) for one cycle of decreased IVDMD. The Ey $\times$ FF High IVDMD Cycle 3 population was selected from the same base population as Trailblazer using three cycles of recurrent restricted phenotypic selection for increased IVDMD (Hopkins et al., 1993). Pathfinder High Yield-DMD Cycle 2 was selected from Pathfinder using two cycles of recurrent restricted phenotypic selection for both increased yield and IVDMD.

Previous year's growth was removed in the fall after a killing frost. All plots at both locations received $122 \mathrm{~kg} \mathrm{~N} \mathrm{ha}^{-1}$ in the form of $\mathrm{NH}_{4} \mathrm{NO}_{3}$ approximately 1 wk following initiation of spring growth. After initiation of spring growth, stand counts were estimated according to methods described by Hopkins et al. (1995). Harvest date and growth stage of subplots were 9 June (vegetative), 19 July (elongating), and 27 August (reproductive) at Ames and 10 June (vegetative), 27 July (elongating), and 26 August (reproductive) at Mead. These dates were chosen to approximate tiller populations selected from the mid-vegetative, mid-elongating, and mid-reproductive stages of morphological development based on the relationship of switchgrass morphological development to day of the year (Mitchell et al., 1992). During this study, all populations at Mead except Cave-in-Rock were infected by a leaf rust (presumably caused by a Puccinia species).

Prior to harvest at each sward maturity, LAI and leaf MTA were determined for each plot, using a LI-COR LAI-2000 leaf area analyzer (LI-COR, ${ }^{1}$ Lincoln, NE) for an indirect measure of canopy architecture as described by Welles and Norman

\footnotetext{
'Mention of a trade name does not constitute a guarantee of the product by the USDA or the Univ. of Nebraska and does not imply its approval to the exclusion of other suitable products.
} 
(1991). Five above-canopy and 20 below-canopy readings were taken. Leaf area index and leaf MTA measurements were taken prior to $1000 \mathrm{~h}$ (daylight time) to reduce the influence of sunlight reflections on canopy estimations.

Plant materials were harvested by hand-clipping all tillers to ground level from a randomly placed $0.1-\mathrm{m}^{2}$ quadrat. Harvested tillers were classified morphologically using the growth staging system for perennial forage grasses described by Moore et al. (1991) to estimate sward maturity on a mean stage by count (MSC) basis.

Further discussion of primary and secondary growth stage descriptions follow the definitions given by Moore et al. (1991). All measurements were made on only one leaf blade and internode per tiller. Measurements of leaf blade length and width were taken from freshly harvested leaves of 10 randomly chosen tillers within the $V_{2}$ secondary stage from vegetative swards. Measurements of leaf blade length and width, and internode length were taken from 10 randomly selected tillers within the $E_{2}$ and $R_{4}$ secondary stages from the elongating and reproductive sward maturities, respectively. These individual stages were chosen to represent the estimated MSC within each sward maturity. Leaf blade length and width were taken from the first fully expanded, collared leaf extending from the top of the whorl (i.e., the most recently collared leaf). Leaf blade length was measured from the leaf collar to the leaf tip. Leaf blade width was measured at the widest portion of the leaf blade. Stem internode length was measured from the midpoint of the first palpable node to the midpoint of the second palpable node.

Tillers separated by growth stage were dried in a forced-draft oven at $55^{\circ} \mathrm{C}$ and weighed to estimate sward maturity on a mean stage by weight (MSW) basis (Moore et al., 1991) and to determine total yield and dry matter (DM) partitioning into leaf blade, leaf sheath, and stem components. Inflorescences were included with the stem fraction. Morphological components of secondary growth stages (Moore et al,, 1991) were pooled according to primary growth stage (vegetative, elongating, reproductive, or seed ripening) to determine DM contribution from individual yield components within each primary growth stage. Total yield estimates were calculated for each
Table 1. Monthly minimum, maximum, and average temperature and total monthly precipitation at Ames, IA, and Mead, NE, during May, June, July, and August 1993.

\begin{tabular}{llrccc}
\hline & & \multicolumn{3}{c}{ Temperature } & \\
\cline { 3 - 5 } Location & Month & Min & Max & Avg. & Precipitation \\
\hline \multirow{4}{*}{ Ames, IA } & & & ${ }^{\circ} \mathrm{C}$ & & mm \\
\cline { 3 - 5 } & May & 3.8 & 28.5 & 13.9 & 122 \\
& June & 5.5 & 31.8 & 19.8 & 188 \\
& July & 11.5 & 37.2 & 22.3 & 351 \\
& August & 12.8 & 33.3 & 17.5 & 267 \\
Mead, NE & May & 2.7 & 33.6 & 15.8 & 69 \\
& June & 6.9 & 35.6 & 22.2 & 193 \\
& July & 13.8 & 35.0 & 22.3 & 173 \\
& August & 10.9 & 34.5 & 23.6 & 155 \\
\hline
\end{tabular}

population by summing the dry weight of the individual morphological components.

The experiment was designed as a randomized complete block with a split-plot arrangement. Whole plots were tiller population and subplots were sward maturities. Locations and blocks nested within location were assumed to be random factors with populations and sward maturities considered fixed factors (McIntosh, 1983). Data were analyzed using the General Linear Model (GLM) procedures of SAS (1985). Linear contrasts were used to compare specific sets of populations. All tests of significance were made at the 0.05 level of probability unless otherwise noted. Numerous higher order interactions were significant for most traits. However, only a small portion of the overall variation was partitioned into these interactions. They were considered biologically insignificant and not deemed important in the interpretation of the results. Stepwise regression (SAS, 1985) was used to predict yield, LAI, and leaf MTA. Terms included in the stepwise regression equations were significant at the 0.15 level of probability.

\section{RESULTS AND DISCUSSION Weather Conditions}

Average monthly temperature was lower at Ames than

Table 2. Total dry matter (DM) yield of sward and leaf blade, leaf sheath, and stem yield (DM basis) for six switchgrass populations at three sward maturities at Ames, IA, and Mead, NE, during 1993.

\begin{tabular}{|c|c|c|c|c|c|c|c|c|c|}
\hline \multirow[b]{2}{*}{ Populationt } & \multirow[b]{2}{*}{ Maturity } & \multicolumn{2}{|c|}{ Total yield } & \multicolumn{2}{|c|}{ Leaf blade dry wt. } & \multicolumn{2}{|c|}{ Leaf sheath dry wt. } & \multicolumn{2}{|c|}{ Stem dry wt. } \\
\hline & & Ames & Mead & Ames & Mead & Ames & Mead & Ames & Mead \\
\hline & & & & & - $\mathbf{k g}$ & $a^{-2}-$ & & & L_ \\
\hline Trailblazer & $\begin{array}{l}\text { Vegetative } \\
\text { Elongating } \\
\text { Reproductive }\end{array}$ & $\begin{array}{l}0.19 \\
0.90 \\
1.16\end{array}$ & $\begin{array}{l}0.30 \\
1.26 \\
1.09\end{array}$ & $\begin{array}{l}0.13 \\
0.38 \\
0.34\end{array}$ & $\begin{array}{l}0.18 \\
0.41 \\
0.30\end{array}$ & $\begin{array}{l}0.06 \\
0.25 \\
0.22\end{array}$ & $\begin{array}{l}0.11 \\
0.29 \\
0.23\end{array}$ & $\begin{array}{l}0 \\
0.27 \\
0.60\end{array}$ & $\begin{array}{l}0.01 \\
0.56 \\
0.56\end{array}$ \\
\hline Pathfinder & $\begin{array}{l}\text { Vegetative } \\
\text { Elongating } \\
\text { Reproductive }\end{array}$ & $\begin{array}{l}0.23 \\
0.91 \\
1.23\end{array}$ & $\begin{array}{l}0.29 \\
1.32 \\
1.42\end{array}$ & $\begin{array}{l}0.15 \\
0.34 \\
0.37\end{array}$ & $\begin{array}{l}0.17 \\
0.38 \\
0.29\end{array}$ & $\begin{array}{l}0.08 \\
0.22 \\
0.25\end{array}$ & $\begin{array}{l}0.10 \\
0.28 \\
0.26\end{array}$ & $\begin{array}{l}0 \\
0.35 \\
0.61\end{array}$ & $\begin{array}{l}0.02 \\
0.66 \\
0.87\end{array}$ \\
\hline Cave-in-Rock & $\begin{array}{l}\text { Vegetative } \\
\text { Elongating } \\
\text { Reproductive }\end{array}$ & $\begin{array}{l}0.22 \\
1.24 \\
2.16\end{array}$ & $\begin{array}{l}0.57 \\
1.40 \\
2.20\end{array}$ & $\begin{array}{l}0.12 \\
0.48 \\
0.54\end{array}$ & $\begin{array}{l}0.33 \\
0.68 \\
0.53\end{array}$ & $\begin{array}{l}0.07 \\
0.30 \\
0.34\end{array}$ & $\begin{array}{l}0.23 \\
0.41 \\
0.35\end{array}$ & $\begin{array}{l}0.03 \\
0.46 \\
1.28\end{array}$ & $\begin{array}{l}0.01 \\
0.31 \\
1.32\end{array}$ \\
\hline Ey $\times$ FF LDMDC1 & $\begin{array}{l}\text { Vegetative } \\
\text { Elongating } \\
\text { Reproductive }\end{array}$ & $\begin{array}{l}0.24 \\
0.92 \\
1.22\end{array}$ & $\begin{array}{l}0.33 \\
1.20 \\
1.33\end{array}$ & $\begin{array}{l}0.16 \\
0.37 \\
0.39\end{array}$ & $\begin{array}{l}0.19 \\
0.40 \\
0.24\end{array}$ & $\begin{array}{l}0.08 \\
0.23 \\
0.24\end{array}$ & $\begin{array}{l}0.11 \\
0.24 \\
0.24\end{array}$ & $\begin{array}{l}0 \\
0.32 \\
0.59\end{array}$ & $\begin{array}{l}0.01 \\
0.56 \\
0.85\end{array}$ \\
\hline Ey $\times$ FF HDMDC3 & $\begin{array}{l}\text { Vegetative } \\
\text { Elongating } \\
\text { Reproductive }\end{array}$ & $\begin{array}{l}0.11 \\
0.72 \\
0.87\end{array}$ & $\begin{array}{l}0.18 \\
1.32 \\
1.48\end{array}$ & $\begin{array}{l}0.08 \\
0.32 \\
0.22\end{array}$ & $\begin{array}{l}0.12 \\
0.54 \\
0.29\end{array}$ & $\begin{array}{l}0.03 \\
0.19 \\
0.19\end{array}$ & $\begin{array}{l}0.05 \\
0.44 \\
0.30\end{array}$ & $\begin{array}{l}0 \\
0.21 \\
0.46\end{array}$ & $\begin{array}{l}0.01 \\
0.74 \\
0.89\end{array}$ \\
\hline Pathfinder HYDMDC2 & $\begin{array}{l}\text { Vegetative } \\
\text { Elongating } \\
\text { Reproductive }\end{array}$ & $\begin{array}{l}0.18 \\
0.90 \\
1.28\end{array}$ & $\begin{array}{l}0.19 \\
1.56 \\
2.41\end{array}$ & $\begin{array}{l}0.12 \\
0.38 \\
0.39\end{array}$ & $\begin{array}{l}0.11 \\
0.51 \\
0.55\end{array}$ & $\begin{array}{l}0.05 \\
0.24 \\
0.22\end{array}$ & $\begin{array}{l}0.06 \\
0.31 \\
0.39\end{array}$ & $\begin{array}{l}0.01 \\
0.28 \\
0.67\end{array}$ & $\begin{array}{l}0.02 \\
0.74 \\
1.47\end{array}$ \\
\hline LSD (0.05) & & & & & & & & & \\
\hline
\end{tabular}

† LDMDC1, Low IVDMD Cycle 1; HDMDC3, High IVDMD Cycle 3; HYDMDC2, High Yield-DMD Cycle 2. 
Table 3. Yield prediction equations using leaf blade (LB), leaf sheath (LS), and stem dry weight per tiller, tiller density (T), and mean stage by count (MSC), and mean stage by weight (MSW) for six switchgrass populations at Ames, IA, and Mead, NE, during 1993.

\begin{tabular}{|c|c|c|c|c|c|}
\hline \multirow[b]{3}{*}{ Population $\dagger$} & \multicolumn{5}{|c|}{ Total dry matter yield } \\
\hline & \multicolumn{3}{|c|}{ Ames } & \multicolumn{2}{|l|}{ Mead } \\
\hline & & Equation & $R^{2}$ & Equation & $R^{2}$ \\
\hline
\end{tabular}

† LDMDC1, Low IVDMD Cycle 1; HDMDC3, High IVDMD Cycle 3; HYDMDC2, High Yield-DMD Cycle 2.

at Mead, except during July, when the average temperature was identical. Wetter than normal conditions occurred during 1993 with more than $100 \mathrm{~mm}$ of rainfall during each month at both locations, except for May at Mead, when $69 \mathrm{~mm}$ of rain fell (Table 1).

\section{Yield}

\section{Total Dry Matter Yield}

Significant location, population, and harvest effects and location $\times$ population $(L \times P)$ interactions occurred for yield $(P<0.05)$. Maximum yields occurred in reproductive swards, except for Trailblazer, which had a small but significant yield decrease for reproductive swards at Mead (Table 2). Yield in reproductive swards at Ames ranged from $0.87 \mathrm{~kg} \mathrm{~m}^{-2}$ (for Ey $\times$ FF High IVDMD Cycle 3) to $2.16 \mathrm{~kg} \mathrm{~m}^{-2}$ (for Cave-in-Rock). A similar range was observed for yield in reproductive swards at Mead: $1.09 \mathrm{~kg} \mathrm{~m}^{-2}$ for Trailblazer to $2.41 \mathrm{~kg} \mathrm{~m}^{-2}$ for Pathfinder High Yield-DMD Cycle 2. The most notable difference was the significant shift in yield ranking within location for Cave-in-Rock and Pathfinder High YieldDMD Cycle 2. These reversed rankings are consistent with the $\mathrm{G} \times \mathrm{E}$ interactions previously reported by Hopkins et al. (1995) for these same two populations.

\section{Yield Prediction}

Leaf blade, leaf sheath, and stem dry weight per tiller, tillers per unit area, mean stage by count, and mean stage by weight were used to predict dry matter yield
(Table 3). The primary yield components should theoretically account for all variation in the yield prediction equations. It was not surprising that MSC and MSW were significant factors for predicting yield in Cave-inRock, Ey $\times$ FF Low IVDMD Cycle 1 , and Pathfinder High Yield-DMD Cycle 2, because DM accumulation should be directly related to plant growth and development. Leaf blade and/or leaf sheath dry weight (DW) per tiller were significant factors for predicting yield in Trailblazer, Pathfinder, and Ey $\times$ FF High IVDMD Cycle 3 (Table 2).

Pathfinder and Pathfinder High Yield-DMD Cycle 2 had similar yields at Ames, but at Mead the yield of Pathfinder High Yield-DMD Cycle 2 was greater than that of Pathfinder. This was due mainly to differences in contribution of tiller size to total DM yield (Table 4). Selection of genotypes for high tiller dry weight increased DM yields of vegetative (Nelson et al., 1985) and reproductive (Sleper and Drolsom, 1974) swards of tall fescue and smooth bromegrass. However, as plant densities increase, tiller size usually decreases (Nelson and Moser, 1994). Trailblazer and Ey $\times$ FF Low IVDMD Cycle 1 had greater yield than Ey $\times$ FF High IVDMD Cycle 3 at Ames, due to major contributions of total leaf blade DW per tiller (Tables 2 and 4) and tiller numbers (Fig. 1). At Mead, conversely, Ey $\times$ FF Low IVDMD Cycle 1 and Ey $\times$ FF High IVDMD Cycle 3 both had greater total yields than Trailblazer, because total stem dry weight made a major contribution (Table

Table 4. Average tiller weight at the vegetative, elongating, reproductive, and seed ripening growth stages for six switchgrass populations grown at Ames, IA, and Mead, NE, during 1993.

\begin{tabular}{|c|c|c|c|c|c|}
\hline \multirow[b]{2}{*}{ Location } & \multirow[b]{2}{*}{ Population $\dagger$} & \multicolumn{4}{|c|}{ Tiller weight } \\
\hline & & Vegetative & Elongating & Reproductive & Seed ripening \\
\hline Ames, IA & $\begin{array}{l}\text { Trailblazer } \\
\text { Pathfinder } \\
\text { Cave-in-Rock } \\
\text { Ey } \times \text { FF LDMDC1 } \\
\text { Ey } \times \text { FF HDMDC3 } \\
\text { Pathfinder HYDMDC2 }\end{array}$ & $\begin{array}{l}0.06 \\
0.03 \\
0.10 \\
0.07 \\
0.06 \\
0.03\end{array}$ & $\begin{array}{l}0.43 \\
0.55 \\
0.76 \\
0.53 \\
0.38 \\
0.50\end{array}$ & $\begin{array}{l}1.52 \\
1.41 \\
2.46 \\
1.38 \\
1.33 \\
1.79\end{array}$ & $\begin{array}{l}-\overline{1} \\
0.27 \\
0.33 \\
0.19 \\
0.12 \\
0.28\end{array}$ \\
\hline LSD (0.05) & & 0.06 & 0.20 & 0.65 & 1.06 \\
\hline
\end{tabular}

† LDMDC1, Low IVDMD Cycle 1; HDMDC3, High IVDMD Cycle 3; HYDMDC2, High Yield-DMD Cycle 2. 


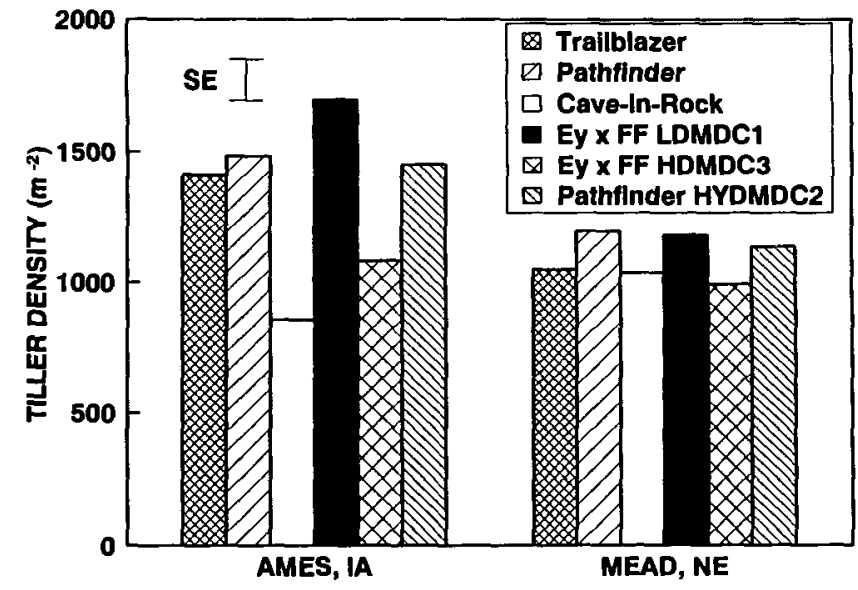

Fig. 1. Tiller density of six switchgrass populations at Ames, IA, and Mead, NE, averaged across three sward maturities.

2). Additionally, leaf sheath dry weight contributed to the total yield of Ey $\times$ FF High IVDMD Cycle 3 .

On a per-tiller basis, contribution by leaf blade and sheath weight varied by location and population with no significant $\mathrm{L} \times \mathrm{P}$ interactions $(P<0.05)$. This suggests that dry weight contributions from individual morphological components were expressed consistently across environments. Generally, leaf blade and leaf sheath fractions accounted for virtually all of the DM accumulation in vegetative swards at both locations (Table 2). In elongating and reproductive swards at Ames, leaf blade and sheath DW per tiller remained constant, whereas stem DW per tiller generally increased. At Mead, leaf blade and sheath DW per tiller generally decreased, whereas stem DW per tiller tended to increase as elongating swards progressed to reproductive sward maturities (Table 2). In elongating swards, the inflorescences of the early reproductive tillers contributed toward total stem weight and may have inflated differences in stem weights in elongating and reproductive swards. The rust infection that occurred in most populations at Mead may have accelerated leaf loss in the infected populations, particularly Trailblazer, which had decreased yield as elongating swards progressed to a reproductive sward maturity.

\section{Mean Stage by Count and Mean Stage by Weight}

Since yield is related to plant developmental morphology, quantification of switchgrass sward development could be a useful tool in yield prediction. If plant maturity within these switchgrass populations had been affected by recurrent restricted phenotypic selection for increased yield or IVDMD, these differences would be manifested in MSC and MSW estimates that quantify sward maturity at the time of harvest (Moore and Moser, 1995). The relationship of MSC to MSW was linear and highly correlated. The equation relating these variables was $y$ $=0.084+1.123 x, r^{2}=0.99$, where $y=$ MSW and $x=$ MSC. However, research by others has shown that MSC tended to underestimate MSW, particularly in reproductive swards, due to greater DM accumulation of stem tissue in tillers of advanced sward maturities
(Kalu and Fick, 1981; Moore et al., 1991). Cave-in-Rock had a greater MSC and MSW than the other populations at both locations (Table 5).

A strong association between growing degree days and morphological development was observed by Sanderson and Wolf (1995), who found vegetative growth to be temperature sensitive and reproductive growth to be photoperiod sensitive. Sims et al. (1971) found that the middle phytomers were responsible for approximately $75 \%$ of the total forage yield in switchgrass. They concluded that the contribution to total dry matter of the last phytomers was primarily by the addition of stem. Similarly, greater than $75 \%$ of the total forage yield had occurred by an elongating sward maturity growth stage with additional yield increases occurring only due to stem accumulation (Table 3).

The difference in yield ranking for Pathfinder High Yield-DMD Cycle 2 and Cave-in-Rock at Mead resulted from increased dry weight contribution from leaf blade, leaf sheath, and stems. This was probably caused by changes in the morphology of Pathfinder High YieldDMD Cycle 2. At Ames, the maximum number of collared leaves prior to elongation $\left(V_{\max }\right)$ was 3 , and the maximum number of palpable nodes prior to seedhead emergence $\left(E_{\max }\right)$ was 8 ; at Mead, $V_{\max }$ and $E_{\max }$ increased to 4 and 9 , respectively. For Cave-in-Rock, however, the values were identical for both Ames and Mead: $V_{\max }$ $=4$ and $E_{\max }=7$. It is not unreasonable to think that this small change in tiller developmental morphology resulted in significant increases in dry weight contributions of the morphological components and thus greatly affected yield. This change in developmental morphology becomes increasingly important, considering that tiller densities were not different between Cave-in-Rock and Pathfinder High Yield-DMD Cycle 2 (Fig. 1).

\section{Plant and Tiller Density}

Plant density varied by location and population. Average plant density for all populations generally was greater at Ames (23.0 plants $\mathrm{m}^{-2}$ ) than at Mead (18.0 plants $\mathrm{m}^{-2}$ ). Averaged across locations, Cave-in-Rock had 22.5 plants $\mathrm{m}^{-2}$. Pathfinder had 22.0 plants $\mathrm{m}^{-2}$, compared with 20.5 plants $\mathrm{m}^{-2}$ for Pathfinder High Yield-DMD Cycle 2. Trailblazer and Ey $\times$ FF Low IVDMD Cycle 1 had similar plant densities (21.0 and 20.0 plants $\mathrm{m}^{-2}$, respectively), compared with 16.5 plants $\mathrm{m}^{-2}$ for Ey $\times$ FF High IVDMD Cycle 3 . Reduced yields would be expected to occur as a result of low plant densities. The reasons for differences in plant density among switchgrass populations selected from the same base populations for increased IVDMD have not been determined. However, in space-planted nurseries, there has been substantial winter-kill of Ey $\times$ FF High IVDMD Cycle 3 (D.R. Buxton, personal communication, 1995; K.P. Vogel, unpublished data, 1995).

Significant location and population effects and $L \times$ $P$ interactions occurred for tiller density $(P<0.05)$. Averaged across sward maturities, tiller density was greater at Ames than Mead. At Ames, Ey $\times$ FF Low IVDMD Cycle 1 had a greater tiller density than the other 
Table 5. Sward maturity estimated as mean stage by count (MSC) and mean stage by weight (MSW) for six switchgrass populations grown at Ames, IA, and Mead, NE, and harvested at three sward maturities during 1993.

\begin{tabular}{|c|c|c|c|c|c|}
\hline \multirow[b]{2}{*}{ Population $\dagger$} & \multirow[b]{2}{*}{ Maturity } & \multicolumn{2}{|c|}{ MSC } & \multicolumn{2}{|c|}{ MSW } \\
\hline & & Ames & Mead & Ames & Mead \\
\hline Trailblazer & $\begin{array}{l}\text { Vegetative } \\
\text { Elongating } \\
\text { Reproductive }\end{array}$ & $\begin{array}{l}1.52(0.19) \ddagger \\
2.30(0.27) \\
2.97(0.47)\end{array}$ & $\begin{array}{l}1.45(0.25) \\
2.72(0.40) \\
3.14(0.50)\end{array}$ & $\begin{array}{l}1.59 \\
2.49 \\
3.31\end{array}$ & $\begin{array}{l}1.57 \\
2.94 \\
3.48\end{array}$ \\
\hline Pathfinder & $\begin{array}{l}\text { Vegetative } \\
\text { Elongating } \\
\text { Reproductive }\end{array}$ & $\begin{array}{l}1.51(0.22) \\
2.35(0.24) \\
2.92(0.38)\end{array}$ & $\begin{array}{l}1.45(0.30) \\
2.71(0.43) \\
3.25(0.55)\end{array}$ & $\begin{array}{l}1.59 \\
2.50 \\
3.21\end{array}$ & $\begin{array}{l}1.61 \\
2.94 \\
3.56\end{array}$ \\
\hline Ey $\times$ FF LDMDC 1 & $\begin{array}{l}\text { Vegetative } \\
\text { Elongating } \\
\text { Reproductive }\end{array}$ & $\begin{array}{l}1.51(0.18) \\
2.28(0.23) \\
2.78(0.47)\end{array}$ & $\begin{array}{l}1.49(0.26) \\
2.62(0.44) \\
3.23(0.54)\end{array}$ & $\begin{array}{l}1.56 \\
2.42 \\
3.13\end{array}$ & $\begin{array}{l}1.62 \\
2.93 \\
3.59\end{array}$ \\
\hline Ey $\times$ FF HDMDC3 & $\begin{array}{l}\text { Vegetative } \\
\text { Elongating } \\
\text { Reproductive }\end{array}$ & $\begin{array}{l}1.49(0.19) \\
2.32(0.26) \\
3.12(0.53)\end{array}$ & $\begin{array}{l}1.41(0.18) \\
2.67(0.47) \\
3.34(0.50)\end{array}$ & $\begin{array}{l}1.55 \\
2.45 \\
3.46\end{array}$ & $\begin{array}{l}1.48 \\
2.89 \\
3.57\end{array}$ \\
\hline
\end{tabular}

† LDMDC1, Low IVDMD Cycle 1; HDMDC3, High IVDMD Cycle 3; HYDMDC2, High Yield-DMD Cycle 2.

$\ddagger$ Values in parentheses are the standard deviation.

populations, whereas Cave-in-Rock had a significantly lower tiller density than the other populations (Fig. 1), but greater forage yield (Table 2). Tiller density of Ey $X$ FF High IVDMD Cycle 3 did not differ across locations. Thus, tiller density may potentially affect developmental morphology. Cave-in-Rock had the greatest MSC and MSW at both locations, with a lower tiller density suggesting a more rapid growth rate.

\section{Morphological Components}

Each switchgrass population was represented by several genotypes (Vogel and Pedersen, 1993). Thus, the genetic representation within each population would be expected to produce a variation in morphological charac- teristics and also differences in morphological development. Significant differences among populations were apparent for leaf blade length and width, internode length, LAI, and leaf MTA. Significant location effects and $\mathrm{L} \times \mathrm{P}$ interactions also occurred for leaf blade width and internode length $(P<0.05)$.

Generally, leaf blades of vegetative and elongating tillers were narrower than leaf blades of reproductive tillers (Table 6). Once the leaf collar has emerged, leaf growth has been completed; however, leaves emerging early in the growing season usually were narrower than those emerging later in the growing season (Nelson and Larson, 1984). More energy may have been required in rapidly growing vegetative and elongating tillers to

Table 6. Leaf blade width, leaf blade length, and stem internode length of six switchgrass populations grown at Ames, IA, and Mead, NE, harvested at three sward maturities during 1993.

\begin{tabular}{|c|c|c|c|c|c|c|c|}
\hline \multirow[b]{2}{*}{ Population $\dagger$} & \multirow[b]{2}{*}{ Maturity } & \multicolumn{2}{|c|}{ Leaf blade width } & \multicolumn{2}{|c|}{ Leaf blade length } & \multicolumn{2}{|c|}{ Stem internode length } \\
\hline & & Ames & Mead & Ames & Mead & Ames & Mead \\
\hline Trailblazer & $\begin{array}{l}\text { Vegetative } \\
\text { Elongating } \\
\text { Reproductive }\end{array}$ & $\begin{array}{l}5.0 \\
4.9 \\
6.4\end{array}$ & $\begin{array}{l}6.3 \\
6.2 \\
7.2\end{array}$ & $\begin{array}{l}22.3 \\
44.3 \\
44.2\end{array}$ & $\begin{array}{l}25.1 \\
43.4 \\
45.6\end{array}$ & $\begin{array}{c}0 \\
14.7 \\
18.9\end{array}$ & $\begin{array}{c}0 \\
9.8 \\
15.6\end{array}$ \\
\hline Pathfinder & $\begin{array}{l}\text { Vegetative } \\
\text { Elongating } \\
\text { Reproductive }\end{array}$ & $\begin{array}{l}5.2 \\
4.6 \\
6.2\end{array}$ & $\begin{array}{l}5.8 \\
4.6 \\
6.8\end{array}$ & $\begin{array}{l}23.2 \\
41.2 \\
41.1\end{array}$ & $\begin{array}{l}23.7 \\
27.4 \\
45.3\end{array}$ & $\begin{array}{l}0 \\
17.4 \\
19.5\end{array}$ & $\begin{array}{c}0 \\
9.2 \\
19.2\end{array}$ \\
\hline Ey $\times$ FF LDMDC 1 & $\begin{array}{l}\text { Vegetative } \\
\text { Elongating } \\
\text { Reproductive }\end{array}$ & $\begin{array}{l}4.8 \\
4.8 \\
6.2\end{array}$ & $\begin{array}{l}5.8 \\
4.7 \\
7.7\end{array}$ & $\begin{array}{l}23.1 \\
45.8 \\
40.4\end{array}$ & $\begin{array}{l}28.0 \\
36.7 \\
43.7\end{array}$ & $\begin{array}{c}0 \\
16.3 \\
18.3\end{array}$ & $\begin{array}{c}0 \\
11.0 \\
19.4\end{array}$ \\
\hline Ey $\times$ FF HDMDC3 & $\begin{array}{l}\text { Vegetative } \\
\text { Elongating } \\
\text { Reproductive }\end{array}$ & $\begin{array}{l}4.6 \\
5.6 \\
7.3\end{array}$ & $\begin{array}{l}6.6 \\
7.3 \\
7.0\end{array}$ & $\begin{array}{l}19.4 \\
43.6 \\
43.8\end{array}$ & $\begin{array}{l}22.7 \\
37.3 \\
40.2\end{array}$ & $\begin{array}{c}0 \\
14.4 \\
17.7\end{array}$ & $\begin{array}{c}0 \\
8.5 \\
16.9\end{array}$ \\
\hline
\end{tabular}

† LDMDC1, Low IVDMD Cycle 1; HDMDC3, High IVDMD Cycle 3; HYDMDC2, High Yield-DMD Cycle 2. 
Table 7. Leaf area index (LAI) and leaf mean tilt angle (MTA) of six switchgrass populations grown at Ames, IA, and Mead, $\mathrm{NE}$, harvested at three sward maturities during 1993 and the LAI and MTA of the six populations averaged across locations and maturities.

\begin{tabular}{lllr}
\hline Factor & Maturity & LAI & MTA \\
\hline Location, across populations & & & \\
Ames, IA & Vegetative & 2.8 & 57.6 \\
& Elongating & 5.5 & 46.2 \\
& Reproductive & 4.9 & 46.0 \\
Mead, NE & Vegetative & 3.4 & 54.9 \\
& Elongating & 5.5 & 44.2 \\
& Reproductive & 4.5 & 48.9 \\
LSD (0.05) & & 0.3 & 2.0 \\
Population, across locations and maturitiesł & & \\
Trailblazer & & 4.0 & 49.9 \\
Pathfinder & & 4.7 & 50.6 \\
Cave-in-Rock & & 4.7 & 46.5 \\
Ey X FF LDMDC1 & & 4.2 & 50.2 \\
Ey X FF HDMDC3 & 4.1 & 51.2 \\
Pathfinder HYDMDC2 & & 4.8 & 49.5 \\
LSD (0.05) & 0.3 & 2.0 \\
\hline
\end{tabular}

† Mean tilt angle (i.e., the inclination angle of the leaf tip) of an erect canopy is $90^{\circ}$.

¥ LDMDC1, Low IVDMD Cycle 1; HDMDC3, High IVDMD Cycle 3; HYDMDC2, High Yield-DMD Cycle 2.

support cellular division in meristematic regions rather than leaf expansion (Brown, 1984).

Differences in leaf blade length of the populations were not associated with increased yield or IVDMD. Shorter leaf blade lengths of reproductive tillers may have been exaggerated, due to leaf tip necrosis in combination with the leaf rust infection. As internode elongation progressed, canopy height was increased. This occurred simultaneously with increases in leaf blade length. Both Trailblazer and Ey $\times$ FF High IVDMD Cycle 3 had shorter internode lengths than Ey $\times$ FF Low IVDMD Cycle 1 at Mead, although internode length did not differ at Ames.

\section{Leaf Area Index and Mean Tilt Angle}

Averaged across populations, location and sward maturity differences were observed for LAI and leaf MTA (Table 7). Leaf area index and leaf MTA were predicted with a multiple regression using leaf blade length and width, internode length, leaf blade, leaf sheath, and stem DW per tiller, and MSC and MSW.

Leaf area index increased with increasing leaf blade length and leaf blade DW per tiller. Conversely, LAI decreased as leaf blade width increased. Although leaf blade length and width were significant factors in the regression, leaf blade DW per tiller was by far the most important in affecting LAI and leaf MTA. The relationship between leaf blade length and width was low $(r=0.22)$ and nonsignificant. Thus, within these switchgrass populations, it should be possible to select for longer leaf blade length without affecting leaf blade width.

Averaged across locations and sward maturities, leaf MTA decreased as leaf blade length increased and leaf blade DW per tiller increased. This suggests that leaf MTA decreased as a result of the simultaneous increase in leaf weight due to increased length. Of the individual canopy measurements, LAI had the strongest association with yield $(r=0.67)$. Leaf blade width was not well correlated with yield or canopy architecture. Although leaf blade length was not correlated highly with yield, it was well correlated with LAI and leaf MTA, which were in turn well correlated with yield. For the switchgrass populations in this study, increased LAI compensated for less erect canopies. The decreased leaf area in old canopies probably resulted from senescence of leaves located toward the bottom of the canopy.

\section{CONCLUSIONS}

Yield was affected primarily by tiller growth and development and the associated morphological modifications occurring in the leaf blades, leaf sheaths, and stems in these divergent switchgrass populations. These same traits of canopy architecture explained observed $\mathrm{G} \times \mathrm{E}$ interactions for yield. Low correlations of yield were associated with all individual canopy traits except possibly LAI (which showed some promise for use as a phenotypic selection criterion). Thus, manipulation of canopy architecture may not be useful in a switchgrass breeding program.

Although direct cause and effect relationships have not been determined, several anomalies in switchgrass developmental morphology were observed. The number of collared leaves prior to elongation and the number of internodes was not identical for all populations within a location, and it also varied for some of the populations across locations. Internode length varied considerably among the populations. Most noteworthy was the difference of internode length among the Ey $\times$ FF population through several cycles of recurrent restricted phenotypic selection for improved IVDMD.

Selection for increased yield and IVDMD caused significant changes in canopy architecture, but the relationship between individual canopy traits and forage yield was variable. For switchgrass strains used as hay or biomass crops, canopies should contain tillers with higher DW. This may result in fewer tillers per unit area, but possibly greater forage yields. If the switchgrass canopy is to be managed for grazing, leaf yield would be more important than total forage yield. If individual canopy traits can be identified as consistent indicators of forage palatability to grazing animals, nutrient density, or nutrient yield, then selection for individual canopy traits may be effective for modifying sward growth habits.

\section{REFERENCES}

Anderson, B., and A.G. Matches. 1983. Forage yield, quality, and persistence of switchgrass and caucasian bluestem. Agron. J. 75; 119-124.

Brougham, R.W. 1958. Interception of light by the foliage of pure and mixed stands of pasture plants. Aust. J. Agric. Res. 9:39-52.

Brown, R.H. 1984. Growth of the green plant. p. 153-174. In M.B. Tesar (ed.) Physiological basis of crop growth and development. ASA and CSSA, Madison, WI.

Carlson, I.T., D.K. Christensen, and R.B. Pearce. 1983. Selection for specific leaf weight in reed canarygrass and its effect on the plant. p. 207-209. In J.A. Smith and V.W. Hays (ed.) Proc. Int. Grassl. Congr., 14th, Lexington, KY. 15-24 June 1981. Westview Press, Boulder, CO. 
Godshalk, E.B., J.C. Burns, and D.H. Timothy. 1986. Selection for in vitro dry matter disappearance in switchgrass regrowth. Crop Sci. 26:943-947.

Griffin, J.L., and G.A. Jung. 1981. Yield and forage quality of Panicum virgatum. p. 491-494. In J.A. Smith and V.W. Hays (ed.) Proc. Int. Grassl. Congr., 14th, Lexington, KY. 15-24 June 1981. Westview Press, Boulder, CO.

Henry, D.S., H.W. Everett, and J.K. Evans. 1976. Clipping effect on stand, yield, and quality of three warm-season grasses. p. 701-704. In J. Luchok et al. (ed.) Hill lands. Proc. Int. Symp., Morgantown, WV. 3-9 Oct. 1976. West Virginia Univ. Office of Publications, Morgantown.

Hopkins, A.A., K.P. Vogel, and K.J. Moore. 1993. Predicted and realized gains from selection for in vitro dry matter digestibility and forage yield in switchgrass. Crop Sci. 33:253-258.

Hopkins, A.A., K.P. Vogel, K.J. Moore, K.D. Johnson, and I.T. Carlson. 1995. Genotype effects and genotype by environment interactions for traits of elite switchgrass populations. Crop Sci. 35:125-132.

Kalu, B.A., and G.W. Fick. 1981. Quantifying morphological development for studies of herbage quality. Crop Sci. 21:267-271.

McIntosh, M.S. 1983. Analysis of combined experiments. Agron. J. 75:153-155.

Mitchell, R.B., K.J. Moore, L.E. Moser, and K.P. Vogel. 1992. Forage quality of switchgrass and big bluestem in relation to morphological development. p. 183. In Agronomy abstracts. ASA, Madison, WI.

Moore, K.J., and L.E. Moser. 1995. Quantifying developmental morphology of perennial grasses. Crop Sci. 35:37-43.

Moore, K.J., L.E. Moser, K.P. Vogel, S.S. Waller, B.E. Johnson, and J.F. Pedersen. 1991. Describing and quantifying growth stages of perennial forage grasses. Agron. J. 83:1073-1077.

Nelson, C.J., and K.L. Larson. 1984. Seedling growth. p. 93-129. In M.B. Tesar (ed.) Physiological basis of crop growth and development. ASA and CSSA, Madison, WI.

Nelson, C.J., and L.E. Moser. 1994. Plant factors affecting forage quality. p. 115-154. In G.C. Fahey, Jr., et al. (ed.) Forage quality, evaluation, and utilization. 13-15 Apr. 1994. Lincoln, NE. ASA, CSSA, and SSSA, Madison, WI.

Nelson, C.J., and D.A. Sleper. 1983. Using leaf-area expansion rate to improve yield of tall fescue. p. 413-416. In J.A. Smith and V.W. Hays (ed.) Proc. Int. Grassl. Congr., 14th, Lexington, KY. 15-24 June 1981. Westview Press, Boulder, CO.

Nelson, C.J., D.A. Sleper, and J.H. Counts. 1985. Field performance of tall fescue selected for leaf-area expansion rate. p. 320-322. In Proc. Int. Grassl. Congr., 15th, Kyoto, Japan. 24-31 Aug. 1985. Sci. Counc. of Japan and Japanese Soc. of Grassl. Sci. c/ o Natl. Grassl Res. Inst., Tochigi-ken, Japan.
Newell, L.C. 1968. Registration of Pathfinder switchgrass. Crop Sci. $8: 516$

Newell, L.C., and S.A. Eberhart. 1961. Clones and progeny evaluation in improvement of switchgrass, Panicum virgatum L. Crop Sci. 1:117-121.

Newell, L.C., and F.D. Keim. 1947. Effects of mowing frequency on the yield and protein content of several grasses grown in pure stands. Nebr. Agric. Exp. Stn. Bull. 150.

Pendleton, J.W., G.E. Smith, S.R. Winter, and T.J. Johnson. 1968 Field investigations of the relationships of leaf angle in corn (Zea mays L.) to grain yield and apparent photosynthesis. Agron. J. 6: 422-424.

Rhodes, I. 1968. Yield of contrasting ryegrass varieties in monoculture and mixed culture. J. Brit. Grassl. Soc. 23:156-158.

Rhodes, I. 1969. The relationship between productivity and some components of canopy structure in ryegrass (Lolium perenne L.): I. Leaf length. J. Agric. Sci. (Camb.) 73:315-319.

Rhodes, I. 1971. The relationship between productivity and some components of canopy structure in ryegrass (Lolium perenne $\mathbf{L}$.): II. Yield, canopy structure and light interception. J. Agric. Sci. (Camb.) 77:283-292.

Rhodes, I. 1975. The relationship between productivity and some components of canopy structure in ryegrass (Lolium perenne L.): IV. Canopy characters and their relationship with sward yield in some intra population selections. J. Agric. Sci. (Camb.) 84:345351 .

Sanderson, M.A., and D.D. Wolf. 1995. Morphological development of switchgrass in diverse environments. Agron. J. 87:908-915.

SAS Institute. 1985. SAS user's guide: Statistics. 5th ed. SAS Inst., Cary, NC.

Sims, P.L., L.J. Ayuko, and D.N. Hyder. 1971. Developmental morphology of switchgrass and sideoats grama. J. Range Manage. 24:357-360.

Sleper, D.A., and P.N. Drolsom. 1974. Analysis of several morphological traits and their associations with digestibility in Bromus inermis Leyss. Crop Sci. 14:34-36.

Stubbendieck, J., S.L. Hatch, C.H. Butterfield. 1992. North American range plants. 4th ed. Univ. of Nebraska Press, Lincoln.

Talbert, L.E., D.H. Timothy, J.C. Burns, J.O. Rawlings, and R.H. Moll. 1983. Estimates of genetic parameters in switchgrass. Crop Sci. 23:725-728.

Tan, W., G. Tan, and P.D. Walton. 1977. Canopy characters and their relationship to spring productivity in Bromus inermis Leyss. Crop Sci. 17:7-10.

Vogel, K.P., F.A. Haskins, H.J. Gorz, B.E. Anderson, and J.K. Ward. 1991. Registration of 'Trailblazer' switchgrass. Crop Sci. 31:1388.

Vogel, K.P., and J.F. Pedersen. 1993. Breeding systems for crosspollinated perennial grasses. Plant Breed. Rev. 11:251-274.

Welles, J.M., and J.M. Norman. 1991. Instrument for indirect measurement of canopy architecture. Agron. J. 83:818-825. 